\title{
Design, synthesis, and biological activity of Schiff bases bearing salicyl and 7-hydroxycoumarinyl moieties
}

\author{
Elżbieta Hejchman ${ }^{1}$ (D) Hanna Kruszewska ${ }^{2} \cdot$ Dorota Maciejewska $^{1} \cdot$ Barbara Sowirka-Taciak $^{1}$. \\ Magdalena Tomczyk $^{1} \cdot$ Alicja Sztokfisz-Ignasiak $^{3} \cdot$ Jan Jankowski $^{3} \cdot$ Izabela Młynarczuk-Biały $^{3}$
}

Received: 24 July 2018 / Accepted: 15 October 2018 / Published online: 10 January 2019

(C) The Author(s) 2019

\begin{abstract}
18 (11 novel) Schiff bases, derivatives of salicylaldehyde, 2-hydroxyacetophenone, and 6-acetyl-, 8-acetyl-, and 8-formyl7-hydroxy-4-methylcoumarin were synthesized and characterized by their spectral studies. 6-Acetyl-7-hydroxy-4-methylcoumarin was prepared by novel method under microwave assistance. These Schiff bases were evaluated for antibacterial activities against 12 bacterial and six fungi strains in vitro. $N$-(3,5-Dichloro-2-hydroxybenzylidene)-4-aminobenzenesulfonic acid sodium salt proved to be the most active against Staphylococcus aureus and MRSA strains (MIC $0.0194 \mu \mathrm{mol} / \mathrm{cm}^{3}$ ). The substitution pattern, two chlorine atoms in the salicylidene ring and the $\mathrm{SO}_{3} \mathrm{Na}$ group, is probably the most beneficial for the activity against Gram-(+) bacteria strains. All Schiff bases were evaluated for cancer efficacy against CFPAC-1 and HeLa cell cultures originating from human pancreas cancer or human cervical cancer. Schiff bases derived from salicylaldehyde are highly effective in pancreas and cervical cancer cells; however, they demonstrate also substantial toxicity towards NIH3T3 cells. Derivatives of coumarin contain three highly selective compounds: 7-hydroxy-8-[(4-methoxyphenylimino)methyl]4-methyl-2H-chromen-2-one, $\mathrm{N}$-[(7-hydroxy-4-methyl-2-oxo- $2 \mathrm{H}$-chromen-8-yl)methylene]-4-aminobenzenesulfonic acid sodium salt, and 7-hydroxy-8-[1-(4-hydroxyphenylimino)ethyl]-4-methyl-2 $\mathrm{H}$-chromen-2-one suggesting more promising potential of the second group of substances.
\end{abstract}

\section{Graphical abstract}
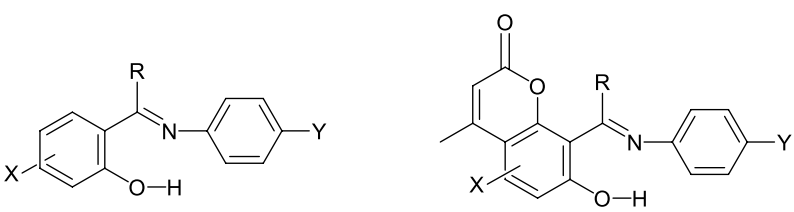

Keywords Antitumor agents $\cdot$ Drug research $\cdot$ Aldehydes $\cdot$ Coumarins $\cdot$ Antimicrobial activity

Electronic supplementary material The online version of this article (https://doi.org/10.1007/s00706-018-2325-5) contains supplementary material, which is available to authorized users.

Elżbieta Hejchman

ehejchman@wum.edu.pl; ehejchman@gmail.com

1 Department of Organic Chemistry, Faculty of Pharmacy, Medical University of Warsaw, 1 Banacha Str, 02097 Warsaw, Poland

2 Department of Antibiotics and Microbiology, National Medicines Institute, 30/34 Chełmska Str, 00725 Warsaw, Poland
Department of Histology and Embryology, Center of Biostructure Research, Medical University of Warsaw, 5 Chałubińskiego Str, 02004 Warsaw, Poland 


\section{Introduction}

Schiff bases, formed in the reaction of aromatic or heteroaromatic substances' primary amine with aldehyde or ketone, are also classified as imines or azomethines. They are a significant class of compounds in medicinal and pharmaceutical chemistry having a variety of biological applications that include antibacterial, antifungal, and antitumor activities. The imine group present in such compounds (of natural as well as synthetic origin) has been shown to be critical to their biological activities [1-4].

The increase in the mortality rate associated with infectious diseases is directly related to antimicrobial resistance to antibiotics [5]. New drugs to combat this problem are, therefore, in great demand [6].

Schiff bases have been shown to be interesting moieties for the design of antimicrobial agents [1-4]. Especially, several Schiff bases having dichloro or bromophenyl moieties have been proved to be biologically important [4]. The presence of halogen atom in the molecule increases the lipophilicity of the molecule and, therefore, affects the partitioning of a molecule into membranes and also facilitates hydrophobic interactions of the molecule with specific binding sites on either receptor or enzymes [7]. Salicylidene (2-hydroxybenzaldehyde-derived) Schiff bases (Fig. 1) are reported as promising antimicrobial drugs $[4,8,9]$.

De Souza reports the determination of the minimal inhibitory concentration (MIC) in vitro for M. tuberculosis H37Rv of a diverse group of compounds, including $\mathrm{N}$-(salicylidene)-derived Schiff bases. The most effective compound among tested samples was $N$-(salicylidene)2-hydroxyaniline (1) with a MIC of $8 \mu \mathrm{mol} / \mathrm{dm}^{3}$. Compound 1 showed a weak cytotoxicity to $\mathrm{J} 774$ macrophages and at $1000 \mu \mathrm{mol} / \mathrm{dm}^{3} 80 \%$ of cells were viable indicating a higher selectivity of the drug to the pathogen than to the mammalian cells. The results for this compound are indicative of the promising antimycobacterial activity of this molecule [8].
A series of 26 Schiff bases were synthesized by reacting 5-chloroaldehyde and primary amines. The compounds were assayed for antibacterial (Bacillus subtilis, Escherichia coli, Pseudomonas fluorescens, and Staphylococcus aureus) and antifungal (Aspergillus niger, Candida albicans, and Trichophyton rubrum) activities by MTT (3-(4,5-dimethylthiazol-2-yl)-2,5-diphenyltetrazolium bromide) method. Among the compounds tested, $(E)$ 4-chloro-2-[(4-fluorobenzylimino)methyl]phenol (2b) showed the most favorable antimicrobial activity with MICs of $45.2,1.6,2.8,3.4$, and $47.5 \mu \mathrm{g} / \mathrm{cm}^{3}$ against $B$. subtilis, E. coli, P. fluorescens, S. aureus, and A. niger, respectively. Compound 2a showed significant activity against $E$. coli $\left(3.1 \mu \mathrm{g} / \mathrm{cm}^{3}\right.$, kanamycin: $\left.3.9 \mu \mathrm{g} / \mathrm{cm}^{3}\right)$. Compound $\mathbf{2 c}$ showed significant activity against $P$. fluorescens $\left(3.1 \mu \mathrm{g} / \mathrm{cm}^{3}\right.$, kanamycin $\left.3.9 \mu \mathrm{g} / \mathrm{cm}^{3}\right)$ and $S$. aureus $(1.8 \mu \mathrm{g} /$ $\mathrm{cm}^{3}$, kanamycin $1 \mu \mathrm{g} / \mathrm{cm}^{3}$, penicillin $2 \mu \mathrm{g} / \mathrm{cm}^{3}$ ).

The authors claimed that increased hydrophilicity and aromaticity, as well as the presence of heteroatoms resulted in an increase in the antimicrobial activity [9].

Hybrid Schiff bases containing salicylidene and sulfonamide moieties show promising antimicrobial activity [10]. 4-[(2-Hydroxybenzylidene)amino]- $N$-(pyrimidin-2-yl)benzenesulfonamides (3) (Fig. 2) were active against $S$. aureus, including a methicillin-resistant strain (MRSA) (MIC values within the range of $0.125-0.250 \mu \mathrm{mol} / \mathrm{cm}^{3}$ [10]. In general, dihalogenation of the salicylic moiety improved the antibacterial and antifungal activity but also increased the cytotoxicity, particularly with an increasing atomic mass.

In the recent few years, the organic compounds containing coumarin Schiff bases as integral part of their structures, in particular, the transition metal complexes, have gained much attention not only because of their antimicrobial [11, 12] but also cytotoxic activity [13]. A variety of coumarinderived Schiff bases have been identified or developed for treatment of different types of cancers $[14,15]$. For example, they have been recently shown to be inhibitors of carbonic anhydrases (CA). Wang and coworkers have designed and synthesized a series of imine-linked sulfonamide-coumarin derivatives [16]. The leading compounds $\mathbf{4 a}$ and $\mathbf{4 b}$ (Fig. 3)
Fig. 1 Salicylidene Schiff bases: $\mathrm{N}$-salicylidene-2-hydroxyaniline (1) and derivatives of 5-chlorosalicylaldehyde (2)<smiles>Oc1ccccc1/C=N/c1ccccc1O</smiles>

1<smiles>[R]N=Cc1cc(Cl)ccc1O</smiles>

$2 a-2 c$

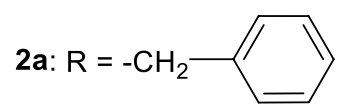

$2 b$<smiles>[R]Cc1ccc(F)cc1</smiles><smiles>[Z]=CCCc1ccc(O)cc1</smiles> 


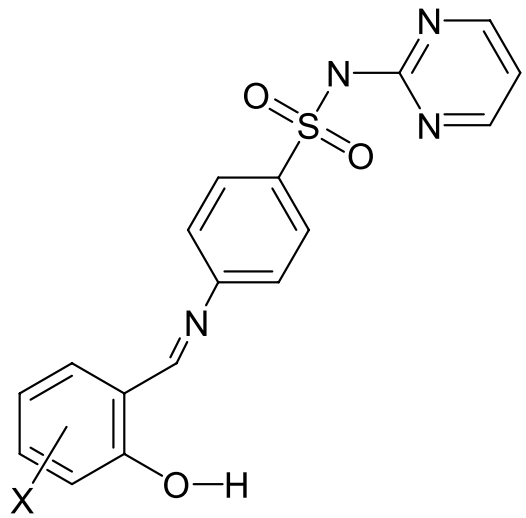

3

\section{$\mathrm{X}=\mathrm{H}$ or $3,5-\mathrm{Cl}, \mathrm{Br}$ or I substituents}

Fig. 2 4-[(2-Hydroxybenzylidene)amino]- $N$-(pyrimidin-2-yl)benzene sulfonamides $\mathbf{3}$<smiles>[R]c1cc([R])c2oc(=O)c(/C=N/c3ccc(S(=O)(=O)Nc4nc([R])cc(C)n4)cc3)c(Cl)c2c1</smiles>

$$
\begin{aligned}
& \text { 4a: } \mathrm{R}^{1}=\mathrm{H}, \mathrm{R}^{2}=\mathrm{CH}_{3} \\
& \text { 4b: } \mathrm{R}^{1}=n-\mathrm{Bu}, \mathrm{R}^{2}=\mathrm{H}
\end{aligned}
$$

Fig. 3 4-Chloro-3-coumarinyl derived Schiff bases $\mathbf{4 a}$ and $\mathbf{4 b}$

were active in vitro against mouse melanoma B16-F10 and MCF7 cells, to obtain the $\mathrm{IC}_{50}$ values $\leq 0.19 \mu \mathrm{M}$. Both compounds inhibited the hCAs II (cytosolic, offtarget isoform)the values of $\mathrm{IC}_{50}$ were $23 \mathrm{nM}$; and hCA IX (transmembrane, tumor associated enzyme)-24 nM, respectively.

To the best of our knowledge, there are no data concerning the biological activity of Schiff bases having benzenesulfonic acid salt moiety combined with halogenated salicylidene or 7-hydroxycoumarin scaffolds. To fill this gap, in the present study, we report the synthesis, characterization, and in vitro cytotoxic and antimicrobial evaluation of a series of hybrid Schiff bases, derived from salicylaldehyde (structure 5a) or 7-hydroxycoumarin scaffold (structure 5b) and para-substituted aniline, with a view to explore their potency as better chemotherapeutic agents (Fig. 4).<smiles>[R]/C(=N\c1ccc([X])cc1)c1ccc([Y])cc1O</smiles>

$5 \mathbf{a}$
$5 b$

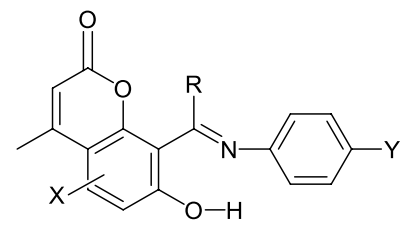

Fig. 4 Design of the novel Schiff bases-a series of compounds having salicylic moiety $(\mathbf{5 a})$ and coumarin moiety $(\mathbf{5 b}) . \mathrm{R}=\mathrm{H}, \mathrm{CH}_{3} ; \mathrm{X}$ and $\mathrm{Y}$ are substituents with various electronic effects

The aim of this study is evaluation of an impact of diverse moieties and substituents in the series of Schiff bases on antimicrobial and cytotoxic activity in vitro and finding preliminary conclusions about the structure-activity relationship. Furthermore, the objective of our work is to prepare a pool of compounds that can be used as ligands in the copper or silver complexes with increased biological activity [1].

\section{Results and discussion}

\section{Chemistry}

The classical synthesis of Schiff base involves the condensation of a carbonyl compound with primary amine. Various in situ methods for water elimination (for example, using dehydrating solvents or molecular sieves or carrying the reaction under azeotropic distillation) were developed. It is known, that efficiency of this synthesis is dependent on the use of highly electrophilic carbonyl components and strongly nucleophilic aromatic amines. If necessary, Brönsted-Lowry or Lewis acids were proposed as catalysts, to activate the carbonyl group of aldehydes or ketones and facilitate the nucleophilic attack by amines, then to eliminate a molecule of water. Recently, several new techniques have been reported. Among these innovations, microwave irradiation has been extensively used due to its operational simplicity, enhanced reaction rates, and great selectivity [4].

Compounds 8-13, derivatives of salicylaldehyde (Fig. 4, structure 5a), were obtained under conditions described in earlier reports [17-19]. Aldehydes 6a-6d were stirred with equimolar amount of appropriate aniline or sodium salt of sulfanilic acid (7a, 7e, 7f) at ambient temperature. Compound $\mathbf{1 4}$ was prepared by heating 2-hydroxyacetophenone and 4-methoxyaniline with the catalyst-lemon juice [20] in xylene at $100{ }^{\circ} \mathrm{C}$ (Scheme 1). The structures of Schiff bases 8-14 are listed in the Table 1.

8-Formyl-7-hydroxy-4-methylcoumarin (15) and 8-acetyl-7-hydroxy-4-methylcoumarin (17) were prepared according to earlier reports $[21,22]$. As the yield of synthesis of 6-acetyl-7-hydroxy-4-methylcoumarin (16c) is 
<smiles>[R]C(=O)c1cc([X])cc([X])c1O</smiles>

6a-6d<smiles>[Y]c1ccc(N[CH])cc1</smiles>

7a, 7e, $7 f$<smiles>[R]C(=Nc1ccc([X])cc1)c1cc([X])cc([Y4])c1O</smiles>

8-14

$$
\mathrm{R}=\mathrm{H}, \mathrm{CH}_{3} \text { i: } \mathrm{MeOH} \text { (compounds 8-13), xylene, lemon juice, } \Delta \text { (compound 14) }
$$

Table 1 The structures of the reported salicylaldehyde-derived Schiff bases 8-14

\begin{tabular}{lllll}
\hline Compounds & $\mathrm{R}$ & $\mathrm{X}^{1}$ & $\mathrm{X}^{2}$ & $\mathrm{Y}$ \\
\hline $\mathbf{8}$ & $\mathrm{H}$ & $\mathrm{H}$ & $\mathrm{H}$ & $\mathrm{OCH}_{3}$ \\
$\mathbf{9}$ & $\mathrm{H}$ & $\mathrm{H}$ & $\mathrm{H}$ & $\mathrm{SO}_{3} \mathrm{Na}$ \\
$\mathbf{1 0}$ & $\mathrm{H}$ & $\mathrm{Cl}$ & $\mathrm{Cl}$ & $\mathrm{SO}_{3} \mathrm{Na}$ \\
$\mathbf{1 1}$ & $\mathrm{H}$ & $\mathrm{Cl}$ & $\mathrm{Cl}$ & $\mathrm{OH}$ \\
$\mathbf{1 2}$ & $\mathrm{H}$ & $\mathrm{Cl}$ & $\mathrm{Cl}$ & $\mathrm{OCH}_{3}$ \\
$\mathbf{1 3}$ & $\mathrm{H}$ & $\mathrm{OCH}_{3}$ & $\mathrm{Br}$ & $\mathrm{SO}_{3} \mathrm{Na}$ \\
$\mathbf{1 4}$ & $\mathrm{CH}_{3}$ & $\mathrm{H}$ & $\mathrm{H}$ & $\mathrm{OCH}_{3}$ \\
\hline
\end{tabular}

low via Fries migration, we have synthesized it by novel method under microwave assistance in about $40 \%$. Heating 7-hydroxy-4-methylcoumarin (16a) with acetic anhydride and anhydrous alumina in methanesulfonic acid resulted in the mixture of 7-acetoxy-4-methylcoumarin (16b) and the only product of Fries rearrangement: 6-acetyl-7-hydroxy4-methylcoumarin (16c). Isolation by column chromatography on silica gel yielded the required compound $\mathbf{1 6} \mathbf{c}$ (Scheme 2). The synthesis of Schiff bases, derivatives of coumarin 18-28 is depicted in Scheme 3.

Schiff bases 18-22, derivatives of coumarin 15, were prepared by traditional but efficient method refluxing the ethanolic mixture of compound $\mathbf{1 5}$, substituted aniline $\mathbf{7 a}$, $\mathbf{7 b}, \mathbf{7 d}, \mathbf{7 e}$, and $\mathbf{7 f}$, and catalytic amount of glacial acetic acid [4]. Coumarin 16 was more reactive, compared to the isomeric compound $\mathbf{1 7}$. The reaction of compound $\mathbf{1 6}$ with 4-methoxyaniline (7f) in xylene at $100{ }^{\circ} \mathrm{C}$ yielded Schiff base 23. Heating of the coumarin $\mathbf{1 7}$ with the corresponding aniline $\mathbf{7} \mathbf{a}-\mathbf{7 g}$ under catalytic amount of lemon juice in xylene resulted in the Schiff bases 24-28. The structures of Schiff bases 15-28 are listed in Table 2.

\section{Microbiology}

Compounds 8-28 were screened in vitro for their antimicrobial activity. The panel of pathogens involved Gram-(+) bacteria strains: Micrococcus luteus, Bacillus subtilis, Staphylococcus aureus, the MRSA strains and Enterococcus hirae; Gram-(-) bacteria strains: Escherichia coli, Pseudomonas aeruginosa; fungi: Candida albicans, Candida parapsilosis, Saccharomyces cerevisiae, Aspergillus brasiliensis. The MIC values of the active compounds are summarized in Table 3.

Salicylidene-derived Schiff bases (compounds 8, 12, 14), coumarins 15, 16a-16c, and 17 as well as coumarinderived Schiff bases (18-23, 25-28) showed no significant antimicrobial activity. $\mathrm{N}$-(2-hydroxybenzylidene)-4-aminobenzenesulfonic acid sodium salt (9) caused only some antifungal activity. $N$-(3,5-dichloro-2-hydroxybenzylidene)4-aminobenzenesulfonic acid sodium salt (10) proved to be the most active against $S$. aureus and MRSA strains (MIC $0.0194 \mu \mathrm{mol} / \mathrm{cm}^{3}$ ). According to the Table 2C from Clinical and Laboratory Standards Institute [23], the susceptibility of Staphylococcus sp. to linezolid, an antibiotic used for the treatment of infections caused by Gram-positive bacteria, is defined as $<0.012-0.024 \mu \mathrm{mol} / \mathrm{cm}^{3}$. Compared with linezolid, the novel compound $\mathbf{1 0}$ is a promising structure for

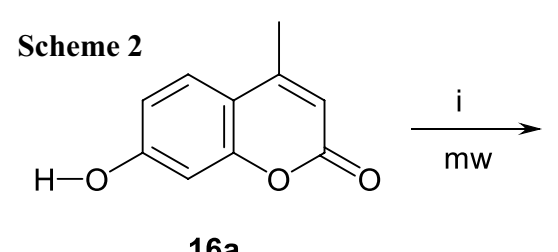

$16 a$

i: $\left.\left(\mathrm{CH}_{3} \mathrm{CO}\right)_{2}\right), \mathrm{CH}_{3} \mathrm{SO}_{3} \mathrm{H}, \mathrm{Al}_{2} \mathrm{O}_{3}$<smiles>CC(=O)Oc1ccc2c(C)cc(=O)oc2c1</smiles>

$16 b$<smiles>CC(=O)c1cc2c(C)cc(=O)oc2cc1O</smiles>

16c 


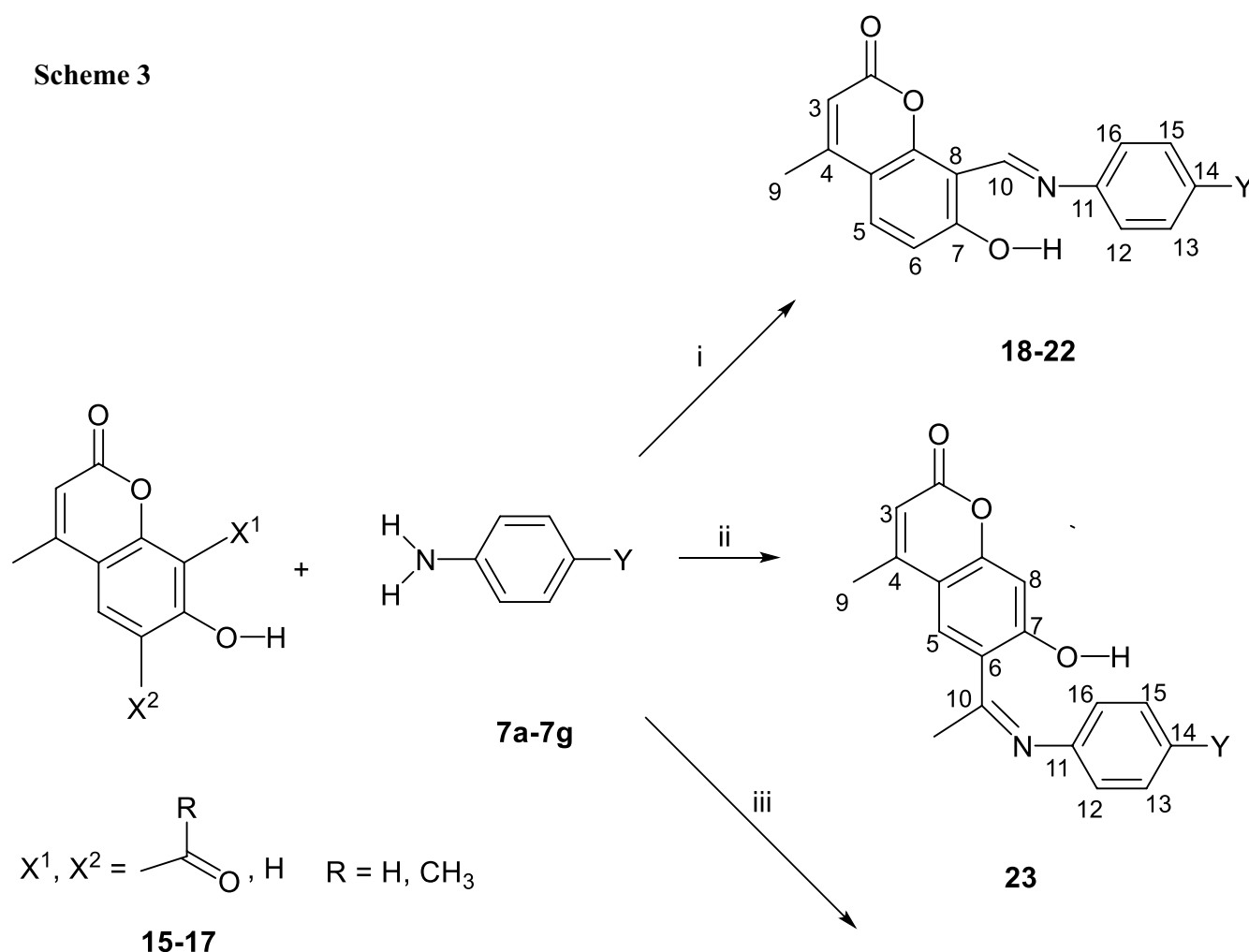

i: $\mathrm{C}_{2} \mathrm{H}_{5} \mathrm{OH}, \mathrm{CH}_{3} \mathrm{COOH}$, reflux

ii: xylene, $100^{\circ} \mathrm{C}$

iii: xylene, $100^{\circ} \mathrm{C}$, lemon juice<smiles>[Y]c1ccc(N=C(C)c2c(OC)ccc3c(C)cc(=O)oc23)cc1</smiles>

24-28

Table 2 The structures of the reported coumarins $\mathbf{1 5 - 1 7}$ and coumarin-derived Schiff bases 18-28

\begin{tabular}{lllll}
\hline Compounds & $\mathrm{R}$ & $\mathrm{X}^{1}$ & $\mathrm{X}^{2}$ & $\mathrm{Y}$ \\
\hline $\mathbf{1 5}$ & - & $\mathrm{H}$ & $\mathrm{HC}=\mathrm{O}$ & - \\
$\mathbf{1 6 c}$ & - & $\mathrm{CH}_{3} \mathrm{C}=\mathrm{O}$ & $\mathrm{H}$ & - \\
$\mathbf{1 7}$ & - & $\mathrm{H}$ & $\mathrm{CH}_{3} \mathrm{C}=\mathrm{O}$ & - \\
$\mathbf{1 8}$ & - & - & - & $\mathrm{Br}$ \\
$\mathbf{1 9}$ & - & - & - & $\mathrm{OH}$ \\
$\mathbf{2 0}$ & - & - & - & $\mathrm{OCH}_{3}$ \\
$\mathbf{2 1}$ & - & - & - & $\mathrm{CH}_{3}$ \\
$\mathbf{2 2}$ & - & - & - & $\mathrm{SO}_{3} \mathrm{Na}$ \\
$\mathbf{2 3}$ & - & - & - & $\mathrm{OCH}_{3}$ \\
$\mathbf{2 4}$ & - & - & - & $\mathrm{OH}$ \\
$\mathbf{2 5}$ & - & - & - & $\mathrm{OCH}_{3}$ \\
$\mathbf{2 6}$ & - & - & - & $\mathrm{OC}_{2} \mathrm{H}_{5}$ \\
$\mathbf{2 7}$ & - & - & - & $\mathrm{CH}_{3}$ \\
$\mathbf{2 8}$ & - & - & - & $\mathrm{C}_{2} \mathrm{H}_{5}$ \\
\hline
\end{tabular}

further research towards potential medicines active against S. aureus strains, including MRSA.

Two other halogenated Schiff bases 11 and $\mathbf{1 2}$ did not possess significant activity against these bacterial strainsreplacement of the sulfonic acid salt substituent present in the compound $\mathbf{1 0}$ by hydroxy (compound 11) or methoxy (compound 12) groups results in reducing the antibacterial activity. The 3-methoxy-5-bromo substitution pattern and presence of the sulfonic substituent in compound $\mathbf{1 3}$ does not provide a beneficial effect on its activity against $S$. aureus and MRSA strains. We conclude that the substitution pattern, two chlorine atoms in the salicylidene ring and the $\mathrm{SO}_{3} \mathrm{Na}$ group, is probably the most beneficial for the activity against Gram-(+) bacteria strains.

Compounds $\mathbf{1 0}$ and $\mathbf{1 3}$ show antifungal activity against C. albicans strains (MIC: 0.0776 and $0.0704 \mu \mathrm{mol} / \mathrm{cm}^{3}$ ). Compared with the susceptibility of Candida sp. to fluconazole, an antifungal medication used for a number of fungal infections which are defined as $<0.026-0.11 \mu \mathrm{mol} / \mathrm{cm}^{3}$ [24], 
Table 3 The antibacterial and antifungal activity of Schiff bases

\begin{tabular}{|c|c|c|c|c|c|c|}
\hline & \multicolumn{6}{|c|}{ Minimal inhibitory concentration (MIC) $/ \mu \mathrm{mol} \mathrm{cm} \mathrm{cm}^{-3}$} \\
\hline & \multicolumn{6}{|c|}{ Compounds } \\
\hline & 9 & 10 & 11 & 13 & 22 & 24 \\
\hline \multicolumn{7}{|l|}{ Bacteria } \\
\hline Micrococcus luteus ATCC 10240 & NA & 0.0388 & 0.440 & 0.2933 & NA & NA \\
\hline Bacillus subtilis ATCC 6633 & NA & 0.0388 & 0.440 & NA & NA & NA \\
\hline Bacillus cereus ATCC 11178 & NA & 0.0388 & 0.440 & NA & NA & 0.404 \\
\hline Staphylococcus epidermidis ATCC 12228 & NA & NA & 0.440 & NA & NA & NA \\
\hline Staphylococcus aureus ATCC 6538 & NA & 0.0194 & 0.440 & NA & NA & NA \\
\hline Staphylococcus aureus ATCC 6538P & NA & 0.0194 & 0.440 & NA & NA & NA \\
\hline MRSA $A 854$ & NA & 0.0194 & 0.440 & NA & NA & NA \\
\hline MRSA $A 876$ & NA & 0.0194 & 0.440 & NA & NA & 0.404 \\
\hline Enterococcus hirae ATCC 10541 & NA & 0.0776 & 0.440 & NA & NA & NA \\
\hline Escherichia coli ATCC 8739 & NA & NA & NA & NA & NA & NA \\
\hline Pseudomonas aeruginosa ATCC 9027 & NA & NA & NA & NA & NA & NA \\
\hline Pseudomonas aeruginosa ATCC 15442 & NA & NA & NA & NA & NA & NA \\
\hline \multicolumn{7}{|l|}{ Fungi } \\
\hline Candida albicans ATCC 10231 & NA & 0.0776 & NA & 0.0704 & NA & NA \\
\hline Candida albicans ATCC 2091 & 0.390 & 0.0776 & 0.440 & 0.0704 & 0.313 & NA \\
\hline Candida parapsilosis ATCC 22019 & NA & 0.1618 & NA & 0.1466 & NA & NA \\
\hline Saccharomyces cerevisiae ATCC 9763 & NA & 0.1618 & NA & 0.2933 & NA & NA \\
\hline Aspergillus brasiliensis ATCC 16404 & NA & 0.1618 & 0.440 & 0.2933 & NA & NA \\
\hline
\end{tabular}

$N A$ not active in concentration below $0.5 \mu \mathrm{mol} / \mathrm{cm}^{3}$ the MICs of compounds $\mathbf{1 0}$ and $\mathbf{1 3}$ look promising. Unfortunately, the use of coumarin scaffold instead of salicylidene for the synthesis of Schiff bases $\mathbf{2 2}$ and $\mathbf{2 4}$ causes a significant reduction in antimicrobial activity.

\section{Cytotoxicity}

Compounds 8-14 and 18-28 were examined in tumor and non-tumor cells to estimate theirs antitumor activity and selectivity. In experiments, we used following cell lines: CFPAC-1 and HeLa originating from human pancreas cancer or human cervical cancer, respectively, as well as mouse NIH-3T3 fibroblasts as non-tumor cells.

Within cytotoxicity assay, inhibitory concentrations required to inhibit $50 \%$ or $90 \%$ of control cell growth were calculated for each cell line and are displayed in the Table 4. According to this, the examined compounds are considered as not effective $\left(\mathrm{IC}_{50}\right.$ values in the range $\left.499 \mu \mathrm{M}-100 \mu \mathrm{M}\right)$, little effective $\left(11 \mu \mathrm{M}<\mathrm{IC}_{50}<99 \mu \mathrm{M}\right)$ and effective $\mathrm{IC}_{50} \leq 10 \mu \mathrm{M}$. All experiments were done three times independently. SD value was in range $\pm 2-15$ for all substances and was omitted for more descriptive results. For better orientation in this table, values that are lower than those for non-tumor fibroblasts are indicated bold.

Coumarins 15, 16a, 16b, 16c, and 17 showed no significant cytotoxic activity. Most of synthesized Schiff bases showed moderate activity against tumor cells and can be categorized into the "little effective group" defined above. In particular, for CFPAC-1 cells compounds: 10-13, 18, 19, 21, 22, and 24 were little effective, whilst in HeLa cells compounds 10, 11, 13, 18-21, and 23-27 were little effective. Compound $\mathbf{2 0}$ for CFPAC-1 cells turned out highly effective. Compounds $\mathbf{8}$ and $\mathbf{9}$ in used concentrations were not effective for both tumor cell lines. HeLa cells turned out to be resistant against compound 22, whereas CFPAC-1 cells were little sensitive to 22 (Table 4 ). However, the $\mathrm{IC}_{50}$ value was relatively high for all tested compounds showing little cytotoxicity compared to known and well-established chemotherapeutics working in vitro in nanomolar concentrations, such as bortezomib. For instance, published so far data with most active imine-linked sulfonamide-coumarin derivatives - demonstrated the $\mathrm{IC}_{50}$ values $\leq 0.19 \mu \mathrm{M}[16]$. In our experiments except for only compound 14 against NIH3T3 cells (IC50 $=4 \mu \mathrm{M})$ and compound 20 against CFPAC-1 cells $(\mathrm{IC} 50=10 \mu \mathrm{M})$, all other substances were less cytotoxic.

The ideal antitumor drug candidate should selectively target tumor cells and be relatively harmless for normal nontumor cells. For assessment of tumor cell selectivity, selectivity index (SI) was calculated and is displayed in Table 5.

According to the definition, selective agents have the SI higher than one [16]. Among novel Schiff bases selective 
Table 4 Compilation of cytostatic/cytotoxic effects by CVDE assay as inhibitory concentrations, $\mathrm{IC}_{50}$ and $\mathrm{IC}_{90}$, respectively, after incubation of given compound for $48 \mathrm{~h}$ with indicated cell line: CFPAC, HeLa or NIH3T3

\begin{tabular}{|c|c|c|c|c|c|c|}
\hline \multirow[t]{4}{*}{ Compounds } & \multicolumn{6}{|c|}{ Inhibitory concentration $\left(\mathrm{IC}_{50}\right.$ or $\left.\mathrm{IC}_{90}\right) / \mu \mathrm{M}$} \\
\hline & \multicolumn{6}{|c|}{ Cell lines } \\
\hline & \multicolumn{2}{|c|}{ CFPAC-1 } & \multicolumn{2}{|l|}{ HeLa } & \multicolumn{2}{|c|}{ NIH3T3 } \\
\hline & $\mathrm{IC}_{50}$ & $\mathrm{IC}_{90}$ & $\mathrm{IC}_{50}$ & $\mathrm{IC}_{90}$ & $\mathrm{IC}_{50}$ & $\mathrm{IC}_{90}$ \\
\hline 8 & $>500$ & $>500$ & $>500$ & $>500$ & 48 & 99 \\
\hline 9 & $>500$ & $>500$ & 320 & $>500$ & 144 & 380 \\
\hline 10 & 32 & 104 & 64 & 116 & 35 & 101 \\
\hline 11 & 54 & 110 & 38 & 123 & 55 & 119 \\
\hline 12 & 51 & 107 & 150 & $>500$ & 42 & 106 \\
\hline 13 & 27 & 107 & 34 & 110 & 30 & 105 \\
\hline 14 & 207 & 350 & 111 & 332 & 4 & 160 \\
\hline 18 & 36 & 120 & 91 & 170 & 62 & 170 \\
\hline 19 & 32 & 115 & 72 & 126 & 43 & 124 \\
\hline 20 & 10 & 120 & 92 & 160 & 96 & 175 \\
\hline 21 & 47 & 122 & 68 & 148 & 71 & 158 \\
\hline 22 & 80 & 142 & $>500$ & $>500$ & 380 & $>500$ \\
\hline 23 & 135 & 190 & 68 & 310 & 72 & 126 \\
\hline 24 & 76 & 100 & 37 & 89 & $>500$ & $>500$ \\
\hline 25 & 207 & 350 & 73 & 144 & 38 & 123 \\
\hline 26 & 207 & 350 & 73 & 144 & 150 & $>500$ \\
\hline 27 & 117 & 150 & 91 & 300 & 91 & 170 \\
\hline 28 & 104 & 132 & 110 & 332 & 68 & 148 \\
\hline
\end{tabular}

$\mathrm{IC}_{50}$ and $\mathrm{IC}_{90}$ is an inhibitory concentration of compound required to inhibit cell proliferation by $50 \%$ or $90 \%$, respectively, in comparison with untreated controls
Table 5 Tumor cell selectivity of novel compounds

\begin{tabular}{lll}
\hline Compounds & NIH3T3/CFPAC-1 & NIH3T3/HeLa \\
\hline 8 & $<1$ & $<1$ \\
9 & $<1$ & $<1$ \\
10 & 1.09 & 0.55 \\
11 & $\mathbf{1 . 0 2}$ & $\mathbf{1 . 4 5}$ \\
12 & 0.82 & 0.28 \\
13 & $\mathbf{1 . 1 1}$ & 0.88 \\
14 & 0.02 & 0.04 \\
18 & $\mathbf{1 . 7 2}$ & 0.68 \\
19 & $\mathbf{1 . 3 4}$ & 0.60 \\
20 & $\mathbf{9 . 6 0}$ & $\mathbf{1 . 0 4}$ \\
21 & $\mathbf{1 . 5 1}$ & $\mathbf{1 . 0 4}$ \\
22 & $\mathbf{4 . 7 5}$ & $<1$ \\
23 & 0.53 & 1.06 \\
24 & $\mathbf{6 . 5 8}$ & $\mathbf{1 3 . 5 1}$ \\
25 & 0.18 & 0.52 \\
26 & 0.72 & $\mathbf{2 . 0 5}$ \\
27 & 0.78 & 1.00 \\
28 & 0.65 & 0.62 \\
\hline
\end{tabular}

Numbers displayed in the table represent the ratio of the $\mathrm{IC}_{50}$ values obtained for non-tumor NIH3T3 vs. $\mathrm{IC}_{50}$ for tumor-derived CFPAC, or HeLa cells, respectively. Bold are numbers demonstrating relative selectivity of the given compound for CFPAC-1 cell line are agents 10, 11, 13, 18-22, and 24, whereas selective for HeLa cells are compounds 11, 20, $\mathbf{2 1}, \mathbf{2 3}, \mathbf{2 4}$, and 26. It is worth to emphasize that three compounds turned out to be highly selective: $\mathbf{2 0 , 2 2}$, and $\mathbf{2 4}$. The most selective compound $\mathbf{2 4}$ has SI yielding approximately 6.5 for CFPAC- 1 , and 13.5 for HeLa cell line. It has to be admitted that this good selectivity of compound 24 is only resulted from insensitivity of NIH3T3 cells to those substances, in this context relatively high $\mathrm{IC}_{50}$ $76 \mu \mathrm{M}$ and $37 \mu \mathrm{M}$ (in CFPAC1 and HeLa cells, respectively), in denominator, gave such a good selectivity index. Compound $\mathbf{2 4}$ is little cytotoxic for tested tumor cell lines and this should be improved to find out it as a potential antitumor drug.

It seems that benzene ring substituted with $\mathrm{OH}$ group in para position added to the coumarin moiety (17) gives the best tumor cell selectivity; however, $\mathrm{IC}_{50}$ for compound $\mathbf{2 4}$ should drop to nanomolar concentrations to talk about the antitumor activity of $\mathbf{2 4}$.

When we compare two chemically different group of compounds, namely derivatives of salicylaldehyde (10-13) and coumarin derivatives (18-28) in context of their anticancer activity, we can take some general conclusions. Schiff bases derived from salicylaldehyde are effective in pancreas and cervical cancer cells; however, they demonstrate also 
substantial toxicity towards NIH3T3 cells. Derivatives of coumarin represented by compounds $\mathbf{1 8}-\mathbf{2 8}$ contain three highly selective compounds $(\mathbf{2 0 - 2 2}, \mathbf{2 4})$ suggesting more promising potential of the second group of substances.

\section{Conclusion}

The present work comprises the new, microwave-assisted method of synthesis of 6-acetyl-7-hydroxy-4-methylcoumarin as well as the preparation of 18 (11 novel) Schiff bases, derivatives of salicylaldehyde, 2-hydroxyacetophenone, and 6-acetyl-, 8-acetyl-, and 8-formyl- 7-hydroxy-4-methylcoumarin. All these compounds were assayed for antimicrobial and cytotoxic activity. Several interesting structure-activity relationships in some Schiff bases were found. The novel compound $N$-(3,5-dichloro-2-hydroxybenzylidene)-4-aminobenzenesulfonic acid sodium salt (10) shows the highest antibacterial activity. It is noteworthy that compound $\mathbf{1 0}$ is soluble in water what potentially makes possible transport of the compound to the interior of the cell or interferences in the structure of the microbial cell membrane.

All but only three compounds $(\mathbf{8}, \mathbf{9}, 22$ on HeLa cells) were active against cancer cells in micromolar concentrations ranging from ca 300 to $10 \mu \mathrm{M}$. Coumarin derivatives turned out to be more selective against cancer cells than derivatives of salicylaldehyde. The most selective compounds are $\mathbf{2 0}$ and 24. Compound $\mathbf{2 0}$ is the Schiff base derived from 8-formyl-7-hydroxy-4-methylcoumarin and 4-methoxyaniline; compound $\mathbf{2 4}$ is derived from 8-acetyl7-hydroxy-4-methylcoumarin and 4-aminophenol. Both compounds are structural isomers differing in the positioning of the methyl group in the molecule. For these molecules, the desirable action is separated from an unwanted toxicity, thus constituting a promising hit for further structure optimization and development of potential anticancer agents. Especially, they are intended to be used as ligands in the copper or silver complexes with potentially increased biological activity.

\section{Experimental}

All reagents were obtained from Sigma-Aldrich and solvents from CHEMPUR S.A. or Polskie Odczynniki Chemiczne S.A. and were used without purification. $100 \%$ lemon juice LEMONDOR from Giancarlo Polenghi was used as a catalyst. All reaction mixtures were monitored using thin-layer chromatography (TLC) on $60 \mathrm{~F}_{254}$ silica gel TLC plates (Merck) (developing system; chloroform-ethyl acetate 20:1). Column chromatography was carried out with silica gel (230-400 mesh) from Merck. Visualization was made with the use of UV laboratory lamp $(\lambda=254,365 \mathrm{~nm})$.
High-resolution accurate mass determinations (HRMS) were recorded in the Faculty of Chemistry the University of Warsaw, on MAS Quattro LCT (TOF) mass spectrometer equipped with electrospray ionization (ESI). Melting points were determined on a ElectroThermal 9001 Digital Melting Point Melting Point apparatus. Nuclear magnetic resonance $\left({ }^{1} \mathrm{H}\right.$ NMR and ${ }^{13} \mathrm{C}$ NMR, HMBC and HSQC) spectra were recorded on a Varian NMRS-300 NMR spectrometer with TMS as an internal standard. Atoms' numbering is presented in Scheme 3. The chemical shifts were reported in parts per million (ppm); the coupling constants $(J)$ were expressed in hertz (Hz). IR spectra ( $\mathrm{KBr}$ or Nujol) were recorded on Shimadzu FTIR 8300 spectrophotometer in the Department of Technology of Drugs and Pharmaceutical Technology, Medical University of Warsaw or FTIR Nicolet iS5 in The Institute of Physics PAN in Warsaw. Elemental analysis (C, $\mathrm{H}, \mathrm{N}, \mathrm{S}$ ) was conducted using the Elemental Analyser Vario EL III (Elementar) in the University of Wrocław, and their results were found to be in good agreement $( \pm 0.3 \%)$ with the calculated values.

2-[(4-Methoxyphenylimino)methyl]phenol (8) Equimolar amounts of salicylaldehyde and 4-methoxyaniline dissolved in ethanol were heated to reflux for $1 \mathrm{~h}$. Then the precipitate was filtered off and dried. Light green solid; yield 62\%; m.p.: 81.5-82.6 ${ }^{\circ} \mathrm{C}$ (lit. $81{ }^{\circ} \mathrm{C}[17]$ ).

$\mathrm{N}$-(2-Hydroxybenzylidene)-4-aminobenzenesulfonic acid sodium salt (9) Sodium salt of compound 9 was prepared according to [18]. Sulfanilic acid (2.5 g, $14.3 \mathrm{mmol})$ was suspended in $25 \mathrm{~cm}^{3}$ methanol and heated to reflux with $0.58 \mathrm{~g}$ powdered sodium hydroxide $(14.4 \mathrm{mmol})$ for $1 \mathrm{~h}$. Then the reaction mixture (white suspension) was left for 10 min at ambient temperature and salicylaldehyde was added dropwise with stirring. Change of color to yellow and precipitation of yellow solid were observed. Stirring was continued for $2 \mathrm{~h}$. The precipitate was filtered off and washed with chloroform. Yellow solid; yield $98 \%$; m.p.: $>300{ }^{\circ} \mathrm{C}$; NMR spectra were found to be identical with the ones described in Ref. [18].

$\mathrm{N}$-(3,5-Dichloro-2-hydroxybenzylidene)-4-aminobenzenesulfonic acid sodium salt $\left(10, \mathrm{C}_{13} \mathrm{H}_{9} \mathrm{Cl}_{2} \mathrm{NO}_{4} \mathrm{~S}\right)$ This product was prepared according to the procedure given for compound 9. Orange solid; yield 74\%; m.p.: $>300{ }^{\circ} \mathrm{C} ;{ }^{1} \mathrm{H}$ NMR (300 MHz, DMSO- $\left.d_{6}\right): \delta=7.44(\mathrm{~d}, J=8.4 \mathrm{~Hz} 2 \mathrm{H}, \mathrm{H}-9,13)$, $7.70(\mathrm{~d}, J=8.4 \mathrm{~Hz}, 2 \mathrm{H}, \mathrm{H}-10,12), 7.74$ (s, 2H, H-4,6), 9.05 (s, $1 \mathrm{H}, \mathrm{H}-7) \mathrm{ppm} ;{ }^{13} \mathrm{C}$ NMR $\left(75 \mathrm{MHz}, \mathrm{DMSO}-d_{6}\right)$ : $\delta=120.44$ (C-1), 120.84 (C-9,13), 121.67 (C-3), 121.94 (C-5), 126.86 (C-10,12), 130.71 (C-6), 132.26 (C-4), 145.89 (C-11), 147.85 (C-8), 156.02 (C-7), 162.42 (C-2) ppm; IR (KBr): $\bar{v}=3455(\mathrm{OH}), 1620(\mathrm{C}=\mathrm{N}), 1320,1045$ (sulfone), 1175 (sulfonate salt), 850 (substitution para di) 
$\mathrm{cm}^{-1}$; HR-MS (TOF, ESI-): $\mathrm{m} / z$ calcd for $\mathrm{C}_{13} \mathrm{H}_{8} \mathrm{Cl}_{2} \mathrm{NO}_{4} \mathrm{~S}$ $\left([\mathrm{M}-\mathrm{H}]^{-}\right)$343.9551, found 343.9546.

\section{4,6-Dichloro-2-[(4-hydroxyphenylimino)methyl]phe-} nol (11) 3,5-Dichloro-2-hydroxybenzaldehyde $(0.955 \mathrm{~g}$, $5 \mathrm{mmol})$ and $0.546 \mathrm{~g} \mathrm{4-aminophenol}(5 \mathrm{mmol})$ were dissolved in $23 \mathrm{~cm}^{3}$ methanol. The mixture was heated to reflux for $1 \mathrm{~h}$ and concentrated; then it was left at ambient temperature. The precipitate was filtered off and purified by crystallization (ethanol). Red solid; yield 76\%; m.p.: $192.9-193.5^{\circ} \mathrm{C}$ (lit. $224{ }^{\circ} \mathrm{C}$ [19]).

\section{4,6-Dichloro-2-[(4-methoxyphenylimino)methyl]phe-} nol (12) 3,5-Dichloro-2-hydroxybenzaldehyde $(0.907 \mathrm{~g}$, $4.75 \mathrm{mmol})$ and $0.585 \mathrm{~g} \mathrm{4-methoxyaniline}(4.75 \mathrm{mmol})$ were dissolved in $13 \mathrm{~cm}^{3}$ methanol. The mixture was left at ambient temperature for $0.5 \mathrm{~h}$. The precipitate was purified by crystallization (ethanol). Orange solid; yield 55\%; m.p.: 114-115 ${ }^{\circ} \mathrm{C}$ (lit. $\left.116^{\circ} \mathrm{C}[19]\right)$.

$\mathrm{N}$-(5-Bromo-2-hydroxy-3-methoxybenzylidene)-4-aminobenzenesulfonic acid sodium salt $\left(13, \mathrm{C}_{14} \mathrm{H}_{12} \mathrm{BrNO}_{5} \mathrm{~S}\right)$ This product was prepared according to the procedure given for compound 9. Red solid; yield 50\%; m.p.: $>300{ }^{\circ} \mathrm{C} ;{ }^{1} \mathrm{H}$ NMR (300 MHz, DMSO- $\left.d_{6}\right): \delta=3.85\left(\mathrm{~s}, 3 \mathrm{H}, \mathrm{OCH}_{3}\right), 7.26$ (d, $J=2.4 \mathrm{~Hz}, \mathrm{H}-4), 7.35$ (d, $J=8.4 \mathrm{~Hz}, 2 \mathrm{H}, \mathrm{H}-9,13), 7.47$ (d, $J=2.4 \mathrm{~Hz}, \mathrm{H}-6), 7.67$ (d, $J=8.4 \mathrm{~Hz}, 2 \mathrm{H}, \mathrm{H}-10,12), 8.95$ (s, $1 \mathrm{H}, \mathrm{H}-7) \mathrm{ppm} ;{ }^{13} \mathrm{C}$ NMR $\left(75 \mathrm{MHz}, \mathrm{DMSO}-d_{6}\right): \delta=55.88$ $\left(\mathrm{OCH}_{3}\right), 117.74(\mathrm{C}-2), 120.30(\mathrm{C}-4), 120.67$ (C-9,13), 125.13 (C-6), 126.80 (C-1), 126.86 (C-10,12), 147.14 (C-8), 149.14 (C-3), 150.07 (C-7) ppm; IR (KBr): $\bar{v}=3700-3400$ $(\mathrm{OH}), 1612(\mathrm{C}=\mathrm{N}), 1320,1045$ (sulfone), 1182 (sulfonate salt), 851 (substitution para di) $\mathrm{cm}^{-1}$; HR-MS (TOF, ESI): $\mathrm{m} / z$ calcd for $\mathrm{C}_{14} \mathrm{H}_{11} \mathrm{BrNO}_{5} \mathrm{~S}\left([\mathrm{M}-\mathrm{H}]^{-}\right)$383.9541, found 383.9534 .

2-[1-(4-Methoxyphenylimino)ethyl]phenol (14) 2-Hydroxyacetophenone $(1.365 \mathrm{~g}, 10 \mathrm{mmol})$ and $1.60 \mathrm{~g}$ 4-methoxyaniline $(13 \mathrm{mmol})$ were dissolved in $5 \mathrm{~cm}^{3}$ xylene. Then the catalyst $1.4 \mathrm{~cm}^{3}$ lemon juice was added. The reaction mixture was stirred magnetically and heated in the oil bath at $100^{\circ} \mathrm{C}$. The progress of reaction was monitored by TLC (chloroform-ethyl acetate 20:1). After $8 \mathrm{~h}$ the mixture was allowed to reach ambient temperature, then it was left in refrigerator for $24 \mathrm{~h}$. Chloroform $\left(10 \mathrm{~cm}^{3}\right)$ and anhydrous $\mathrm{MgSO}_{4}$ were added to remove water. Then the filtrate was concentrated and the resulting precipitate was filtered off. The crude compound was purified by crystallization (methanol). Yellow solid; yield 23\%; m.p.: $101-103{ }^{\circ} \mathrm{C}$ (lit. $98-99{ }^{\circ} \mathrm{C}$ [25]).

8-Formyl-7-hydroxy-4-methyl-2H-chromen-2-one (15) Offwhite solid; yield $11 \%$; m.p.: $182-184{ }^{\circ} \mathrm{C}$ (lit. $174-176{ }^{\circ} \mathrm{C}$ [21]).
6-Acetyl-7-hydroxy-4-methyl-2H-chromen-2-one (16c) 7-Hydroxy-4-methylcoumarin $\left(\mathbf{1 6}^{\mathrm{a}}, 8.80 \mathrm{~g}, 50 \mathrm{mmol}\right)$ was dissolved in $35 \mathrm{~cm}^{3}$ methanesulfonic acid (540 mmol). Then $35 \mathrm{~cm}^{3}$ acetic anhydride $(370 \mathrm{mmol})$ and $40 \mathrm{~g}$ anhydrous alumina ( $390 \mathrm{mmol}$ ) were added. The reaction mixture was heated in microwave oven; conditions: two cycles of heating, time: $4 \mathrm{~min}$ (reflux), power: $500 \mathrm{~W}$. Then the mixture was allowed to reach ambient temperature and filtered through silica gel under reduced pressure. The filtrate was poured to $60 \mathrm{~g}$ ice water and extracted with dichloromethane $\left(3 \times 60 \mathrm{~cm}^{3}\right)$. The organic layer was washed with saturated aqueous solution of $\mathrm{NaHCO}_{3}$. Solvent was evaporated and the product 2 was isolated by column chromatography on silica gel 230-400 mesh (chloroform-ethyl acetate). Colorless solid; yield $42 \%$; m.p.: $207-208{ }^{\circ} \mathrm{C}$ (lit. $210-211{ }^{\circ} \mathrm{C}$ [26]); ${ }^{1} \mathrm{H}$ and ${ }^{13} \mathrm{C}$ NMR spectra were found to be identical with the ones described in Ref. [26].

8-Acetyl-7-hydroxy-4-methyl-2H-chromen-2-one (17) Colorless solid; yield $80 \%$; m.p.: $174-175{ }^{\circ} \mathrm{C}$ (lit. 174-175 $\left.{ }^{\circ} \mathrm{C}[26]\right) ;{ }^{1} \mathrm{H}$ and ${ }^{13} \mathrm{C}$ NMR spectra were found to be identical with the ones described in Ref. [26].

8-Formyl-7-hydroxy-4-methyl-2H-chromen-2-one (15) derived Schiff bases-general procedure Compound $\mathbf{1 5}$ ( $0.408 \mathrm{~g}, 2 \mathrm{mmol})$, appropriate aniline or the sodium salt of sulfanilic acid ( $2 \mathrm{mmol}$ ) were dissolved in $5 \mathrm{~cm}^{3}$ ethanol, one drop of glacial acetic acid was added, and the mixture was magnetically stirred and heated to reflux in the oil bath (1-4 h). The progress of reaction was monitored by TLC (chloroform-ethyl acetate 20:1). When the reaction was complete, the mixture was left at ambient temperature overnight. The precipitate was filtered off under reduced pressure, and purified by crystallization (ethanol).

7-Hydroxy-8-[(4-bromophenylimino)methyl]-4-methyl-2H-chromen-2-one $\left(18, \mathrm{C}_{17} \mathrm{H}_{12} \mathrm{BrNO}_{3}\right)$ This product was prepared according to the general procedure. Orange solid; yield $68 \%$; m.p.: $222-223.5{ }^{\circ} \mathrm{C} ; R_{f}=0.68 ;{ }^{1} \mathrm{H}$ NMR (300 MHz, $\mathrm{CDCl}_{3}$ ): $\delta=2.43(\mathrm{~d}, J=1.2 \mathrm{~Hz}, 3 \mathrm{H}, \mathrm{H}-9), 6.16$ (bq, $J=1.2 \mathrm{~Hz}, 1 \mathrm{H}, \mathrm{H}-3$ ), 6.95 (d, $J=9 \mathrm{~Hz}, 1 \mathrm{H}, \mathrm{H}-6), 7.24$ 7.29 (m, 2H, H-12,16), 7.55-7.60 (m, 2H, H-13,15), 7.61 (d, $J=9 \mathrm{~Hz}, 1 \mathrm{H}, \mathrm{H}-5), 9.36$ (s, 1H, H-10) ppm; ${ }^{13} \mathrm{C}$ NMR (75 MHz, $\mathrm{CDCl}_{3}$ ): $\delta=19.18(\mathrm{C}-9), 107.18(\mathrm{C}-8), 111.44$ (C-3), 111.63 (C-4a), 114.87 (C-6), 121.52 (C-14), 123.25 (C-12,16), 129.68 (C-5), 132.88 (C-13,15), 153.41 (C-4), 157.28 (C-8a,10), 160.36 (C-2), 166.06 (C-7) ppm; IR (Nujol): $\bar{v}=1710(\mathrm{C}=\mathrm{O}), 1620(\mathrm{C}=\mathrm{N}) \mathrm{cm}^{-1}$; HR-MS (TOF, ESI-): $m / z$ calcd for $\mathrm{C}_{17} \mathrm{H}_{11} \mathrm{NO}_{3} \mathrm{Br}\left([\mathrm{M}-\mathrm{H}]^{-}\right) 355.9922$, found 355.9915.

7-Hydroxy-8-[(4-hydroxyphenylimino)methyl]-4-methyl-2H-chromen-2-one $\left(19, \mathrm{C}_{17} \mathrm{H}_{13} \mathrm{NO}_{4}\right)$ This product was 
prepared according to the general procedure. Orange solid; yield 60\%; m.p.: $253{ }^{\circ} \mathrm{C}$ (decomposition); $R_{f}=0.65 ;{ }^{1} \mathrm{H}$ NMR $\left(300 \mathrm{MHz}\right.$, DMSO- $\left.d_{6}\right): \delta=2.42(\mathrm{~d}, J=0.9 \mathrm{~Hz}, 3 \mathrm{H}$, H-9), 6.24 (bq, $J=0.9 \mathrm{~Hz}, 1 \mathrm{H}, \mathrm{H}-3), 6.85-6.90$ (m, 2H, $\mathrm{H}-13,15), 6.91$ (d, $J=9 \mathrm{~Hz}, 1 \mathrm{H}, \mathrm{H}-6), 7.39-7.44$ (m, 2H, H-12,16), 7.77 (d, J=9 Hz, 1H, H-5), 9.19 (s, 1H, H-10), 9.81 (s, $1 \mathrm{H}, \mathrm{H}-10) \mathrm{ppm} ;{ }^{13} \mathrm{C}$ NMR $\left(75 \mathrm{MHz}, \mathrm{DMSO}-d_{6}\right)$ : $\delta=18.40(\mathrm{C}-9), 106.22(\mathrm{C}-8), 110.18(\mathrm{C}-3), 110.69(\mathrm{C}-4 \mathrm{a})$, 114.31 (C-6), 116.16 (C-13,15), 122.75 (C-12.16), 129.81 (C-5), 137.34 (C-11), 153.17 (C-10), 153.81 (C-8a), 154.06 (C-4), 157.54 (C-14), 159.25 (C-2), 165.67 (C-7) ppm; IR (Nujol): $\bar{v}=3250(\mathrm{O}-\mathrm{H}), 1696(\mathrm{C}=\mathrm{O}), 1622(\mathrm{C}=\mathrm{N}) \mathrm{cm}^{-1}$.

7-Hydroxy-8-[(4-methoxyphenylimino)methyl]-4-methyl-2H-chromen-2-one $\left(20, \mathrm{C}_{18} \mathrm{H}_{15} \mathrm{NO}_{4}\right)$ This product was prepared according to the general procedure. Orange solid; yield 69\%; m.p.: $203.7-205.6{ }^{\circ} \mathrm{C} ; R_{f}=0.46 ;{ }^{1} \mathrm{H} \mathrm{NMR}$ (300 MHz, $\mathrm{CDCl}_{3}$ ): $\delta=2.42(\mathrm{~d}, J=0.9 \mathrm{~Hz}, 3 \mathrm{H}, \mathrm{H}-9), 3.86$ (s, 3H, C14-OCH $)_{3}$ ), 6.14 (bq, J=0.9 Hz, 1H, H-3), 6.96 (d, $J=9 \mathrm{~Hz}, 1 \mathrm{H}, \mathrm{H}-6)$ 6.95-7.00 (m, 2H, H-13,15), 7.40-7.56 (m, 2H, H-12,16), 7.58 (d, $J=9 \mathrm{~Hz}, 1 \mathrm{H}, \mathrm{H}-5), 9.33$ (s, 1H, $\mathrm{H}-10) \mathrm{ppm} ;{ }^{13} \mathrm{C} \mathrm{NMR}\left(75 \mathrm{MHz}, \mathrm{CDCl}_{3}\right): \delta=19.18(\mathrm{C}-9)$, $55.81\left(\mathrm{C} 14-\mathrm{OCH}_{3}\right), 107.16(\mathrm{C}-8), 111.06$ (C-3), 111.18 (C-4a), 114.99 (C-13,15), 115.21 (C-6), 122.75 (C-12.16), 129.09 (C-5), 139.45 (C-11), 153.54 (C-8a), 154.28 (C-4), 154.57 (C-10), 159.68 (C-2), 160.61 (C-14), 166.4 (C-7) ppm; IR (Nujol): $\bar{v}=1721(\mathrm{C}=\mathrm{O}), 1602(\mathrm{C}=\mathrm{N}), 1379$ (C-O-Casym) $\mathrm{cm}^{-1}$; HR-MS (TOF, ESI-): $\mathrm{m} / \mathrm{z}$ calcd for $\mathrm{C}_{18} \mathrm{H}_{14} \mathrm{NO}_{4}\left([\mathrm{M}-\mathrm{H}]^{-}\right)$308.0923, found 308.0924.

\section{7-Hydroxy-8-[(4-methylphenylimino)methyl]-4-me-} thyl-2H-chromen-2-one (21) This product was prepared according to the general procedure. Orange solid; yield 57\%; m.p.: $196.5-199.0{ }^{\circ} \mathrm{C}$ (lit. $188-189^{\circ} \mathrm{C}$ [27]).

$\mathrm{N}$-[(7-Hydroxy-4-methyl-2-oxo-2H-chromen-8-yl) methylene]-4-aminobenzenesulfonic acid sodium salt (22, $\mathrm{C}_{17} \mathrm{H}_{13} \mathrm{NO}_{6} \mathrm{~S}$ ) This product was prepared according to the general procedure. Orange solid; yield $90 \%$; m.p.: $>300{ }^{\circ} \mathrm{C}$; ${ }^{1} \mathrm{H}$ NMR (300 MHz, DMSO- $d_{6}$ ): $\delta=2.43$ (s, 3H, H-9), 6.26 (d, $J=0.9 \mathrm{~Hz}, 1 \mathrm{H}, \mathrm{H}-3), 6.95$ (d, $J=9 \mathrm{~Hz}, 1 \mathrm{H}, \mathrm{H}-6)$,7.48 (d, $J=8.4 \mathrm{~Hz}, 2 \mathrm{H}, \mathrm{H}-12,16), 7.71(\mathrm{~d}, J=8.4 \mathrm{~Hz}, 2 \mathrm{H}, \mathrm{H}-13,15)$, $7.82(\mathrm{~d}, J=9.0 \mathrm{~Hz}, 1 \mathrm{H}, \mathrm{H}-5), 9.28(\mathrm{~s}, 1 \mathrm{H}, \mathrm{H}-10) \mathrm{ppm} ;{ }^{13} \mathrm{C}$ NMR (75 MHz, DMSO- $d_{6}$ ): $\delta=18.37$ (C-9), 106.20 (C-8), 110.38 (C-3), 110.88 (C-4a), 114.29 (C-6), 120.72 (C-12,16), 126.96 (C-13,15), 130.63 (C-5), 145.94 (C-14), 147.62 (C-11), 154.00 (C-8a), 154.12 (C-4), 156.89 (C-10), 159.11 (C-2), 165.62 (C-7) ppm; IR (Nujol): $\bar{v}=3260(\mathrm{OH}), 1728$ $(\mathrm{C}=\mathrm{O}), 1610(\mathrm{C}=\mathrm{N}), 1319,1050$ (sulfone), 1180 (sulfonate salt), 849 (substitution para di) $\mathrm{cm}^{-1}$; HR-MS (TOF, ESI): $\mathrm{m} / z$ calcd for $\mathrm{C}_{17} \mathrm{H}_{12} \mathrm{NO}_{6} \mathrm{~S}\left([\mathrm{M}-\mathrm{H}]^{-}\right) 358.0385$, found 358.0380 .
7-Hydroxy-6-[1-(4-methoxyphenylimino)ethyl]-4-methyl-2H-chromen-2-one $\left(23, \mathrm{C}_{19} \mathrm{H}_{17} \mathrm{NO}_{4}\right)$ Coumarin $16 \mathrm{c}$ $(10 \mathrm{mmol})$ and $1.60 \mathrm{~g} \mathrm{4-methoxyaniline}(13 \mathrm{mmol})$ were dissolved in $5 \mathrm{~cm}^{3}$ xylene. The reaction mixture was stirred magnetically and heated in the oil bath at $100{ }^{\circ} \mathrm{C}$. The progress of reaction was monitored by TLC (chloroform-ethyl acetate 20:1). After $6 \mathrm{~h}$ the mixture was allowed to reach ambient temperature, then it was left in refrigerator for $24 \mathrm{~h}$. Chloroform $\left(10 \mathrm{~cm}^{3}\right)$ and anhydrous $\mathrm{MgSO}_{4}$ were added to remove water. Then the filtrate was concentrated and the resulting precipitate was filtered off. The crude compound was purified by crystallization (methanol). Yellow solid; yield 83\%; m.p.: $239-241{ }^{\circ} \mathrm{C} ; R_{f}=0.57 ;{ }^{1} \mathrm{H}$ NMR $(300 \mathrm{MHz}$, acetone- $\left.d_{6}\right): \delta=2.53(\mathrm{~d}, 3 \mathrm{H}, J=3.0 \mathrm{~Hz}, \mathrm{H}-9), 2.77-2.80(\mathrm{~m}$, $3 \mathrm{H}, \mathrm{C} 10-\mathrm{CH}_{3}$ ), 3.84 (s, 3H, C14-OCH ${ }_{3}$ ), 6.12 (bs, 1H, H-3), $6.75(\mathrm{~d}, 1 \mathrm{H}, J=4.2 \mathrm{~Hz}, \mathrm{H}-8), 7.03$ (m, 4H, H-12,13,15,16), 8.13 (s, 1H, H-5) ppm; ${ }^{13} \mathrm{C}$ NMR (75.4 MHz, acetone- $\left.d_{6}\right)$ :

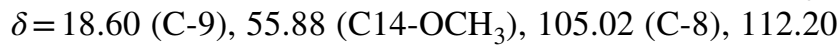
(C-3), 112.32 (C-4a), 115.36 (C-13,15), 123.89 (C-6), 123.97 (12,16), 128.22 (C-5), 139.77 (C-11), 153.95 (C-4), 158.66 (C-8a), 160.57 (C-2), 167.14 (C-7), 172.81 (C-10) ppm; IR (KBr): $\bar{v}=2841,1723(\mathrm{C}=\mathrm{O}), 1612(\mathrm{C}=\mathrm{N}), 1500$ $\left(\mathrm{C}=\mathrm{C}\right.$ ), 858 (substitution para $\mathrm{di}$ ) $\mathrm{cm}^{-1}$; HR-MS (TOF, $\mathrm{ESI}+$ ): $m / z$ calcd for $\mathrm{C}_{19} \mathrm{H}_{17} \mathrm{NNaO}_{4}\left([\mathrm{M}+\mathrm{Na}]^{+}\right) 346.1055$, found 346.1049 .

8-Acetyl-7-hydroxy-4-methyl-2H-chromen-2-one (17) derived Schiff bases-general procedure Coumarin $\mathbf{1 7}$ $(10 \mathrm{mmol})$ and appropriate aniline $(13 \mathrm{mmol})$ were dissolved in $5 \mathrm{~cm}^{3}$ xylene. Then the catalyst $-1.4 \mathrm{~cm}^{3}$ lemon juice - was added. The reaction mixture was stirred magnetically and heated in the oil bath at $100{ }^{\circ} \mathrm{C}$. The progress of reaction was monitored by TLC (chloroform-ethyl acetate 20:1). After $8 \mathrm{~h}$ the mixture was allowed to reach ambient temperature, then it was left in refrigerator for $24 \mathrm{~h}$. Chloroform $\left(10 \mathrm{~cm}^{3}\right)$ and anhydrous $\mathrm{MgSO}_{4}$ were added to remove water. Then the filtrate was concentrated and the resulting precipitate was filtered off. The crude compound was purified by crystallization (methanol).

7-Hydroxy-8-[1-(4-hydroxyphenylimino)ethyl]-4-methyl-2H-chromen-2-one (24) This product was prepared according to the general procedure. Yellow solid; yield 85\%; m.p.: 256-257 ${ }^{\circ} \mathrm{C}$ (lit. $217^{\circ} \mathrm{C}[28]$ ); ${ }^{1} \mathrm{H}$ NMR spectrum was found to be different from the one described in Ref. [28].

7-Hydroxy-8-[1-(4-methoxyphenylimino)ethyl]-4-methyl-2H-chromen-2-one $\left(25, \mathrm{C}_{19} \mathrm{H}_{17} \mathrm{NO}_{4}\right)$ This product was prepared according to the general procedure. Yellow solid; yield 87\%; m.p.: $198-200{ }^{\circ} \mathrm{C} ; R_{f}=0.48 ;{ }^{1} \mathrm{H}$ NMR (300 MHz, acetone- $\left.d_{6}\right): \delta=2.47(\mathrm{~d}, 3 \mathrm{H}, J=1.2 \mathrm{~Hz}, \mathrm{H}-9)$, $2.68\left(\mathrm{~m}, 3 \mathrm{H}, \mathrm{C} 10-\mathrm{CH}_{3}\right), 3.85\left(\mathrm{~s}, 3 \mathrm{H}, \mathrm{C} 14-\mathrm{OCH}_{3}\right), 6.11$ (s, $1 \mathrm{H}, \mathrm{H}-3), 6.89$ (dd, 1H, J=9.0, 3.6 Hz, H-6), 7.03-7.12 
(m, 4H, H-12,13,15,16), 7.75 (d, 1H, J=9.0 Hz, H-5) ppm; ${ }^{13} \mathrm{C}$ NMR (75.4 MHz, acetone- $\left.d_{6}\right): \delta=19.15$ (C-9), 33.99 $\left(\mathrm{C} 10-\mathrm{CH}_{3}\right), 55.79\left(\mathrm{C} 14-\mathrm{OCH}_{3}\right), 110.41(\mathrm{C}-4 \mathrm{a}), 111.68$ (C-3), 114.96 (C-13,15), 115.37 (C-6), 116.34 (C-8), 121.43 (C-12,16), 129.81 (C-5), 133.01 (C-7), 146.12 (C-11), 154.56 (C-8a), 154. 89 (C-4), 159.55 (C-2), 160.13 (C-10,14) ppm; IR (KBr): $\bar{v}=3001,2964,1709(\mathrm{C}=\mathrm{O})$, $1597(\mathrm{C}=\mathrm{N}), 1502(\mathrm{C}=\mathrm{C}), 827$ (substitution para $\mathrm{di}) \mathrm{cm}^{-1}$; HR-MS (TOF, ESI-): $m / z$ calcd for $\mathrm{C}_{19} \mathrm{H}_{16} \mathrm{NO}_{4}\left([\mathrm{M}-\mathrm{H}]^{-}\right)$ 322.1079 , found 322.1073 .

7-Hydroxy-8-[1-(4-ethoxyphenylimino)ethyl]-4-methyl-2H-chromen-2-one $\left(26, \mathrm{C}_{20} \mathrm{H}_{19} \mathrm{NO}_{4}\right)$ This product was prepared according to the general procedure. Yellow solid; yield 76\%; m.p.: $167-170{ }^{\circ} \mathrm{C} ; R_{f}=0.39 ;{ }^{1} \mathrm{H}$ NMR $(300 \mathrm{MHz}$, acetone- $\left.d_{6}\right): \delta=1.40(\mathrm{t}, 3 \mathrm{H}, J=6.9 \mathrm{~Hz}, \mathrm{H}-19), 2.47$ (d, $3 \mathrm{H}, J=0.9 \mathrm{~Hz}, \mathrm{H}-9), 2.67,2.69$ (m, 3H, C14- $\mathrm{OCH}_{2} \mathrm{CH}_{3}$ ), $4.10\left(\mathrm{q}, 2 \mathrm{H}, J=6.9 \mathrm{~Hz}, \mathrm{C} 14-\mathrm{OCH}_{2} \mathrm{CH}_{3}\right), 6.11(\mathrm{~s}, 1 \mathrm{H}$, $\mathrm{H}-3), 6.88(\mathrm{~d}, 1 \mathrm{H}, J=8.7 \mathrm{~Hz}, \mathrm{H}-6), 7.02-7.11(\mathrm{~m}, 4 \mathrm{H}$, $\mathrm{H}-12,13,14,15,16), 7.75(\mathrm{~d}, 1 \mathrm{H}, J=9.0 \mathrm{~Hz}, \mathrm{H}-5) \mathrm{ppm} ;{ }^{13} \mathrm{C}$ NMR (75.4 MHz, acetone- $\left.d_{6}\right): \delta=15.25\left(\mathrm{C} 14-\mathrm{OCH}_{2} \mathrm{CH}_{3}\right)$, 19.19 (C-9), 64.14 (C-11), $64.40\left(\mathrm{C} 14-\mathrm{OCH}_{2} \mathrm{CH}_{3}\right), 110.40$ (C-4a), 111.70 (C-3), 115.27 (C-13,15), 116.00 (C-6), 121.40 (12,16), 124.35 (C-11), 129.78 (C-5), 133.03 (C7), 154.53 (C-8a), 154.79 (C-4), 160.09 (C-2), 168.61 (C-14), 173.12 (C-10) ppm; IR (KBr): $\bar{v}=2984,1722(\mathrm{C}=\mathrm{O}), 1590$ $(\mathrm{C}=\mathrm{N}), 1507(\mathrm{C}=\mathrm{C}), 832$ (substitution para di) $\mathrm{cm}^{-1}$; HR-MS (TOF, ESI-): $m / z$ calcd for $\mathrm{C}_{20} \mathrm{H}_{18} \mathrm{NO}_{4}\left([\mathrm{M}-\mathrm{H}]^{-}\right.$) 336.1236 , found 336.1234 .

\section{7-Hydroxy-8-[1-(4-methylphenylimino)ethyl]-4-me-} thyl-2H-chromen-2-one $\left(27, \mathrm{C}_{19} \mathrm{H}_{17} \mathrm{NO}_{3}\right)$ This product was prepared according to the general procedure. Yellow solid; yield $81 \%$; m.p.: $149-150{ }^{\circ} \mathrm{C} ; R_{f}=0.54 ;{ }^{1} \mathrm{H}$ NMR (300 MHz, acetone- $\left.d_{6}\right): \delta=2.37$ (s, 3H, C14-CH ${ }_{3}$ ), 2.47 (d, $3 \mathrm{H}, J=1.2 \mathrm{~Hz}, \mathrm{H}-9), 2.65-2.80\left(\mathrm{~m}, 3 \mathrm{H}, \mathrm{C} 10-\mathrm{CH}_{3}\right), 6.12$ (br.s, 1H, H-3), 6.89 (d, 1H, J=9.3 Hz, H-6), 7.15 (d, 2H, $J=9.0 \mathrm{~Hz}, \mathrm{H}-13,15), 7.30$ (d, 2H, $J=7.8 \mathrm{~Hz}, \mathrm{H}-14,16), 7.76$ $(\mathrm{d}, 1 \mathrm{H}, J=9.0 \mathrm{~Hz}, \mathrm{H}-5) \mathrm{ppm} ;{ }^{13} \mathrm{C}$ NMR $(75 \mathrm{MHz}$, acetone$\left.d_{6}\right): \delta=19.15$ (C-9), $21.02\left(\mathrm{C} 14-\mathrm{CH}_{3}\right), 34.00(\mathrm{C}-11), 111.67$ (C-8), 113.10 (C-4a), 115.24 (C-6), 115.39 (C-3), 120.26 (C-12,16), 129.85 (C-5), 130.78 (C-13,15), 133.00 (C-14), 146.82 (C-11), 150.41 (C-4), 154.56 (C-8a), 154.80 (C-10), 159.60 (C-2), 160.09 (C-7) ppm; IR (KBr): $\bar{v}=3023(\mathrm{OH})$, 2985, $1722(\mathrm{C}=\mathrm{O}), 1603(\mathrm{C}=\mathrm{N}), 1505(\mathrm{C}=\mathrm{C}), 839$ (substitution para di) $\mathrm{cm}^{-1}$; HR-MS (TOF, ESI + ): $\mathrm{m} / \mathrm{z}$ calcd for $\mathrm{C}_{19} \mathrm{H}_{17} \mathrm{NNaO}_{3}\left([\mathrm{M}+\mathrm{Na}]^{+}\right) 307.1208$ found 307.1186 .

7-Hydroxy-8-[1-(4-ethylphenylimino)ethyl]-4-methyl-2H-chromen-2-one $\left(28, \mathrm{C}_{20} \mathrm{H}_{19} \mathrm{NO}_{3}\right)$ This product was prepared according to the general procedure. Yellow solid; yield $61 \%$; m.p.: $122-123{ }^{\circ} \mathrm{C} ; R_{f}=0.53 ;{ }^{1} \mathrm{H}$ NMR $(300 \mathrm{MHz}$, acetone- $\left.d_{6}\right): \delta=1.26$ (t, $\left.3 \mathrm{H}, J=7.5 \mathrm{~Hz}, \mathrm{C} 14-\mathrm{CH}_{2} \mathrm{CH}_{3}\right), 2.47$ (d, 3H, $J=0.9 \mathrm{~Hz}, \mathrm{H}-9), 2.64-2.80$ (m, 5H, $\mathrm{C} 10-\mathrm{CH}_{2} \mathrm{CH}_{3}$ ), 6.12 (br.s, $1 \mathrm{H}, \mathrm{H}-3$ ), 6.93 (d, 1H, $J=9.0 \mathrm{~Hz}, \mathrm{H}-6), 7.04$ (d, $2 \mathrm{H}, J=8.1 \mathrm{~Hz}, \mathrm{H}-13,15), 7.32$ (d, 2H, $J=8.1 \mathrm{~Hz}, \mathrm{H}-14,16$ ), 7.76 (d, 1H, $J=8.7 \mathrm{~Hz}, \mathrm{H}-5), 13.40$ (s, 1H, C7-OH) ppm; ${ }^{13} \mathrm{C}$ NMR $\left(75 \mathrm{MHz}\right.$, acetone- $\left.d_{6}\right) \delta=18.18\left(\mathrm{C} 14-\mathrm{CH}_{3}\right), 33.01$ (C-11, C14- $\left.\mathrm{CH}_{2}-\mathrm{CH}_{3}\right), 110.70$ (C-8), 114.28 (C-3), 114.43 (C-4a), 119.31 (C-6), 119.42 (C-12,16), 128.13 (C-5), 132.04 (C-13,15), 134.00 (C-14), 146.62 (C-11), 151.41 (C-4), 156.46 (C-8a), 155.81 (C-10), 161.59 (C-2), 160.39 (C-7) ppm; IR $(\mathrm{KBr}): \bar{v}=2962,2930,1667(\mathrm{C}=\mathrm{O}), 1600(\mathrm{C}=\mathrm{N}), 1514$ $\left(\mathrm{C}=\mathrm{C}\right.$ ), 835 (substitution para di) $\mathrm{cm}^{-1}$; HR-MS (TOF, ESI-): $\mathrm{m} / \mathrm{z}$ calcd for $\mathrm{C}_{20} \mathrm{H}_{18} \mathrm{NO}_{3}\left([\mathrm{M}-\mathrm{H}]^{-}\right)$320.1289, found 320.1292.

\section{In vitro antibacterial activity assay}

\section{Strains}

The following microbial strains were chosen from American Type Culture Collection (ATCC): Gram-(+) bacteria strains: Micrococcus luteus 10240, Bacillus subtilis 6633, Staphylococcus aureus (6538, 6538P), Enterococcus hirae 10541; Gram-(-) bacteria strains: Escherichia coli 8739, Pseudomonas aeruginosa $(9027,15442)$; fungi (yeast strains): Candida albicans (10231, 2091), Candida parapsilosis 22019, Saccharomyces cerevisiae 9763; fungi (mold strain): Aspergillus brasiliensis 16404 . The MRSA hospital strains (methicillin-resistant $S$. aureus) from Clinical Hospital Prof. Orlowski in Warsaw collection: A854 (isolated from throat mucosa, 30.03.2011) resistance: CIP, E, DA, AK and A876 (isolated from lower leg injury, 19.02.2012) resistance: E, DA, CIP, AK.

\section{Antimicrobial activity: preliminary test}

In the preliminary tests, antimicrobial activity was determined by a modified cylinder-plate method. Stainless steel cylinders of $6 \mathrm{~mm}$ diameter were put on a Mueller-Hinton two agar (for bacteria strains) or Sabouraud agar (for yeast strains) plate inoculated with one of the tested strains. An aliquot of $100 \mathrm{~mm}^{3}$ of each compound in concentration of $10 \mathrm{mg} / \mathrm{cm}^{3}$ (dissolved in $10 \%$ DMSO, in a $0.08 \mathrm{M}$ phosphate buffer, $\mathrm{pH}$ 7.0) was placed into the cylinder. As a negative control 10\% DMSO (in $0.08 \mathrm{M}$ phosphate buffer, $\mathrm{pH} 7.0$ ) without any compound was used. The plates with bacterial strains were incubated at $37^{\circ} \mathrm{C}$ for $24 \mathrm{~h}$, whereas plates with yeast strains at $30^{\circ} \mathrm{C}$ for $48 \mathrm{~h}$. The inhibition of bacterial growth was observed as a halo around the cylinder containing the tested compound. Size of inhibition zone reflected an antimicrobial activity of the compound.

\section{Minimum inhibitory concentration}

For the compounds, which showed some activity against any of the tested strains, a minimum inhibitory concentration 
(MIC) was determined based on M7-A9 method [23]. The stock solution was prepared by dissolving each compound in DMSO. A series of gradient solutions in the range from 1 to $0.0156 \mathrm{mg} / \mathrm{cm}^{3}$ was obtained by the double dilution in $0.08 \mathrm{M}$ phosphate buffer ( $\mathrm{pH} 7.0$ ). The $250 \mathrm{~mm}^{3}$ aliquot of the successive dilution of tested compound was mixed with $4.75 \mathrm{~cm}^{3}$ of a liquefied Mueller-Hinton two or Sabouraud agar, precooled to $45^{\circ} \mathrm{C}$. The suspension of the particular strain of density 0.5 unit (McFarland scale) was diluted ten times and aliquot of $2 \mathrm{~mm}^{3}$ was applied on agar plate surface. The lowest concentration of tested compound, which totally inhibited growth of the examined strain, was taken as MIC value. As a negative control the solution of the highest concentration of DMSO in $0.08 \mathrm{M}$ phosphate buffer ( $\mathrm{pH} 7.0$ ) was used. All tests were performed in triplicates. In control samples, MIC values of ciprofloxacin ranging between 0.08 and $1.36 \times 10^{-3} \mu \mathrm{mol} / \mathrm{cm}^{3}$ for bacterial strains.

\section{In vitro antitumor activity assay}

\section{Cell culture}

The influence of novel compounds on growth and proliferation of cells was studied in three established mammalian cell lines. We performed experiments in two cancer cell lines: CFPAC - human pancreatic cancer cell line and HeLa cells-human cervical cancer cell line. As a non-tumor cell line NIH3T3 fibroblasts were investigated. All cell lines were from ATCC. Cells were cultured exponentially in RPMI1640 (CFPAC) or in DMEM (HeLa and NIH3T3). The culture media containing stable glutamine were supplemented with $10 \%$ fetal bovine serum and standard antibiotics. All are from Biochrom, Germany. Cells were kept in a humidified atmosphere of $5 \% \mathrm{CO}_{2}$, at $37{ }^{\circ} \mathrm{C}$ and passaged every 3 days.

\section{Crystal violet dye elution (CVDE) assay}

For estimation of cytostatic/cytotoxic effects of experimental compounds, cells were seeded into 96-well flat-bottom plates at a density of $10^{5}$ cells/well in $100 \mathrm{~mm}^{3}$ of culture medium. After adhesion of cells, particular compounds were added in a range of concentrations $1-500 \mu \mathrm{M}$ for $48 \mathrm{~h}$. As a control, cells were incubated with solvent only. After $48 \mathrm{~h}$ of incubation with compounds, medium was removed and CVDE assay was performed as described in Reference [29]. According to the growth inhibition induced by particular drug, a dose-response curve was drawn and inhibitory concentrations, $\mathrm{IC}_{50}$ and $\mathrm{IC}_{90}$, respectively, were estimated.

Acknowledgements This project was supported by Medical University of Warsaw, Faculty of Pharmacy, FW24/NM1/17.
Open Access This article is distributed under the terms of the Creative Commons Attribution 4.0 International License (http://creativeco mmons.org/licenses/by/4.0/), which permits unrestricted use, distribution, and reproduction in any medium, provided you give appropriate credit to the original author(s) and the source, provide a link to the Creative Commons license, and indicate if changes were made.

\section{References}

1. Chaturvedi D, Kamboj M (2016) Chem Sci J 7:2

2. Kajal A, Bala S, Kamboj S, Sharma N, Saini V (2013) J Catalysts. https://doi.org/10.1155/2013/893512

3. Qin W, Long S, Panunzio M, Biondi S (2013) Molecules 18:12264

4. da Silva CM, da Silva DL, Modolo LV, Alves RB, de Resende MA, Martins CVB, de Fatima A (2011) J Adv Res 22:1

5. Cosgrove SA (2006) Clin Infect Dis 42:S82

6. https//amr-review.org//sites/default/files/securing new drugs for future generations final web_0.pdf. Accessed 24.09.2018

7. Karthikeyan MS, Prasad DJ, Poojary B, Bhat KS, Holla BS, Kumarib NS (2006) Bioorg Med Chem 14:7482

8. de Souza AO, Galetti FCS, Silva CL, Bicalho B, Parma MM, Fonseca SF, Marsaioli AJ, Trindade ACLB, Rossimíriam P, Gil F, Bezerra FS, Andrade-Neto M, de Oliveira MCF (2007) Quim Nova 30:1563

9. Shi L, Ge H-M, Tan S-H, Li H-Qi, Song Y-C, Zhu H-L, Tan R-Xi (2007) Eur J Med Chem 42:558

10. Krátký M, Dzurková M, Janoušek J, Kone`cná K, Trejtnar F, Stola ríková J, Vinšová J (2017) Molecules 22:1573

11. Prabhakara CT, Patil SA, Toragalmath SS, Kinnal SM, Badami PS (2016) J Photochem Photobiol B 157:1

12. Satyanarayana VSV, Sreevani P, Sivakumar A, Vijayakumar V (2008) Arkivoc 2008(17):221-233

13. Utreja D, Sarbjit Singh V, Kaur M (2015) Curr Bioact Compd 11:215

14. Emami S, Dadashpour S (2015) Eur J Med Chem 102:611

15. Kaur M, Kohli S, Sandhu S, Bansal Y, Bansal G (2015) AntiCancer Agents Med Chem 15:1032

16. Wang Z-C, Qin Y-J, Wang P-F, Yang Y-A, Wen Q, Zhang X, Qiu H-Y, Duan Y-T, Wang Y-T, Sang Y-L, Zhu H-L (2013) Eur J Med Chem 66:1

17. Frischmann PD, Jiang J, Hui JKH, Grzybowski JJ, MacLachlan MJ (2008) Org Lett 10:1255

18. Robert F, Naik AD, Hidara F, Tinant B, Robiette R, Wouters J, Garcia Y (2010) Eur J Org Chem 4:621-637

19. Cronenberger L, Gaigé T, Pachéco H (1968) Bull Soc Chim Biol 50:929

20. Patil S, Jadhav SD, Patil UP (2012) Arch Appl Sci Res 4:1074

21. Al-Kawkabani A, Boutemeur-Kheddis B, Makhloufi-Chebli M, Hamdi M, Talhi O, Silva AMS (2013) Tetrahedron Lett 54:5111

22. Hejchman E, Maciejewska D, Wolska I (2008) Monatsh Chem 139:1337

23. Clinical and Laboratory Standards Institute (2012) Performance standards for antimicrobial susceptibility testing; Approved standard M7-A9, Methods for dilution antimicrobial susceptibility tests for bacteria that grow aerobically, 9th edn. CLSI, Wayne

24. Clancy CJ, Yu VL, Morris AJ, Snydman DR, Nguyen MH (2005) Antimicrob Agents Chemother 49:3171

25. Hothi HS, Makkar JR, Sharma JR, Manrao MR (2006) Eur J Med Chem 41:253

26. Yadav P, Satapathi S, Kumaria M, Chaturvedi A, Li L, Samuelson LA, Kumarb J, Sharma SK (2014) J Photochem Photobiol A 280:39

27. Traven VF, Ivanov IV, Panov AV, Safronova OB, Chibisova TA (2008) Russ Chem Bull 57:1989

28. Balaji PN, Seleena SKP, Gummadi V, Tummala H, Bodhanapu N, Thummala L (2013) Res J Pharm Biol Chem Sci 4:9

29. Młynarczuk-Biały I, Roeckmann H, Kuckelkorn U, Schmidt B, Umbreen S, Gołąb J (2006) J Cancer Res 66:7598 